\title{
EFL LEARNERS' PRODUCTION OF IDIOMATIC EXPRESSIONS IN SPEAKING
}

\author{
Yunie Amalia Rakhmyta ${ }^{1}$, Rusmiati ${ }^{2}$ \\ ${ }^{1,2}$ Department of English Education, Tarbiyah Faculty, IAIN Takengon. Indonesia \\ Email: amalia.nirfan@gmail.com ${ }^{1}$, rusmiatiza19@gmail.com ${ }^{2}$
}

\begin{abstract}
Idiomatic expressions are expressions whose meanings cannot be derived from their literal meaning. Thus, it is viewed as a challenging part for EFL learners in either understanding or practicing them. However, using them in oral spoken adequately signifies that someone is a proficient English user. This research is carried out to depict the learner's application of idiomatic expressions in spoken English. It is performed to address the accompanying examination questions: (1) Do EFL learners of the English Department in IAIN Takengon use idiomatic expressions in speaking? (2) What type of idioms do they produce in speaking? (3) What is the most frequently used idiom type in their speaking?. 20 students' recordings were collected and analyzed using the descriptive qualitative method. The result shows that the learners use idiomatic expressions. The learners produced only three types of idiomatic expressions, namely phrasal verb idiom, tournures idiom, and irreversible compound idiom. Of all, phrasal verb idiom is the most frequently used. It is suggested that the learners are encouraged to be exposed to English more often to apply more idiomatic expressions in their speaking.
\end{abstract}

Keywords: Idiomatic Expressions, EFL Learners, Speaking

\begin{abstract}
Abstrak: Ekspresi idiomatik adalah ekspresi yang maknanya tidak dapat diturunkan dari makna literalnya. Karenanya, hal ini dipandang sebagai sesuatu yang menantang terutama untuk mahasiswa yang mempelajari bahasa asing seperti bahasa Inggris, baik dalam memahami atau mempraktikkannya. Penggunaan idiom secara lisan cukup menandakan kemahiran seseorang dalam berbicara bahasa Inggris. Penelitian ini dilakukan untuk menggambarkan pemakaian ekspresi idiomatik oleh pembelajar bahasa Inggris secara lisan. Pertanyaan penelitian ini diantaranya: Apakah pembelajar EFL di IAIN Takengon menggunakan ekspresi idiomatik dalam berbicara? (2) Jenis idiom apa yang mereka hasilkan dalam berbicara?, dan (3) Jenis idiom apa yang paling sering digunakan dalam pembicaraan mereka?. Untuk mengetahuinya, 20 hasil rekaman suara dikumpulkan dan akan diuraikan menggunakan metode deskriptif kualitatif. Hasil akhirnya menunjukkan bahwa pembelajar EFL menggunakan ekspresi idiomatik dalam penggunaan lisan bahasa Inggris namun tidak banyak jenisnya, hanya tiga tipe ekspresi idiomatik yang mereka gunakan yaitu idiom phrasal verb, Idiom tournures, dan Idiom irreversible compound. Secara keseluruhan, Idiom phrasal verb adalah yang paling sering digunakan. Disarankan agar pembelajar EFL lebih berani dan lebih sering berbicara dalam bahasa Inggris sehingga mereka dapat menggunakan lebih banyak ekspresi idiomatik saat berbicara.
\end{abstract}

Kata Kunci: Ekspresi Idiomatik, Pembelajar EFL, Berbicara

\section{INTRODUCTION}

Idiomatic expressions such as metaphors, action words, phrases, and all non-literal discourse will always overflowing in a language (Cooper, 1999). Idiomatic expressions, also known as idioms, are considered an essential element in learning English. They are part of native speakers' life which are very widely used in their communication. These expressions are even found in argumentative essays written to TOEFL prompts in large quantities (Flor \& Beigman Klebanov, 2018). Cooper (1999) in (Zarei \& Rahimi, 2012) 
states that applying appropriate idiomatic expressions would be regarded as being close to the native speaker in all languages since she noted that almost all the English speakers say around 20 million idioms per lifetime; thus, idioms play a crucial role in learning a foreign language. (Onjukka, 2011) also emphasizes the significance of idioms in language learning that the learners' competence in a language can be increased by identifying and applying idiomatic expressions. However, they can be problematic when EFL learners are unfamiliar with the expressions since communication cannot be reached when EFL learners do not understand native's spoken. Glucksberg (2008: 88), in Bastug and Salihagic (2014), points out that mastering applying idioms is both essential and difficult in language learning. It is supported by Maisa's and Karunakaran's findings, which stated that most teachers agree that idiomatic expressions are important in everyday English usage and include the hardest part of English for the foreign learners (Maisa \& Karunakaran, 2013).

Furthermore, Healey (1968: 71), as cited in (Alata et al., 2016), defined idiomatic expressions as a series of words from which their meaning cannot form the meaning of the expressions. For instance, the phrase "kill two birds with one stone" does not have anything to do with stone and birds. It does not signify throwing a stone toward two birds to kill them. Instead, it means to get two results or benefits in only one action. Such meaning is likely to be implicit or hidden and should be comprehended in a context. Velasco states that daily utterances of English native speakers are littered with many idiomatic expressions that would sound strange or even weird to non-native speakers (Velasco, 2016).

Due to the implied meaning of the idiomatic expression, it is difficult for EFL learners to catch it. Warren (2005) in (Vanderniet, 2015) says that due to naturally memorizing idioms (because is read/listened to repeatedly), non-English speakers can recognize (learn) the meanings of those (idiom expressions). Glucksberg (2001) in (AlKhawaldeh et al., 2016) also argues that identifying idioms in a language can provide the learners with its culture since it is unique and hard to find the relevant meanings in other languages. Normally, when EFL learners find unfamiliar words, they can search the individual word meaning in a dictionary and then try to combine the meaning of those words. However, this solution cannot be applied when they find unfamiliar words that are idiomatic expressions since individual words cannot regulate their meaning in phrases or clauses. Bobrow and Bell claimed the idiom is bountiful in regular speech but uncommon 
as the subject of mental exploration (Bobrow \& Bell, 1973). Thus, idiomatic expressions are regarded as a challenging part for EFL learners to master. One of the plans to get a decent comprehension of idiomatic expressions articulations is that the learners must introduce more into the objective language.

Conversely, due to the hardship in extracting the significance of idiomatic expressions and their wide use by the locals, the EFL learners who can understand and apply in speaking are considered more proficient. Students having sufficient insight into idiomatic expressions will be better speakers because a natural, conversational, and creative sense of a language is obtained (Edith, 2009). This assessment agrees with Rana, who expressed that the lot of a non-local speaker of English is supplied for utilizing idiomatic expressions, the nearer the person to English fluency (Rana, 2016). It is in line with (Bastug \& Salihagic, 2014) that prominent an EFL student is viewed as cutting edge if she or he aces the utilization of idioms.

This article sheds light on the importance of using them to understand or practice in daily life. An investigation, therefore, was done to EFL learners of the English Department in IAIN Takengon. Its purpose is to find out a description of how is the use of idiomatic expressions in speaking. To specify, the research questions proposed are (1) Do EFL learners use idiom expressions in speaking? (2) What type of idioms do they produce in speaking? (3) What is the most frequently used idiom type in their speaking?

\section{LITERATURE REVIEW}

\section{Idiom}

Experts provide many definitions of idiomatic expressions. Mc Carthy and O'Dell expressed that idioms are fixed expressions whose implies is not immediately clear from noticing the individual words inside itself (McCarthy \& Dell, 2017). According to Irujo (1986), learners often face difficulty identifying whether an idiom contains an idiomatic or literal meaning in particular contexts. Besides, an idiom is defined as several words forming a meaning as a whole, which is different from each word's meaning when they are separated (Mc. Mordiew, 1983:4). Rohani and Ketabi (2012) in (Asri, 2017) also said that an idiom is a figurative expression that can have a literal meaning, yet when applied in a particular context, it contains a non-literal meaning. From those definitions, it tends to be summarized that the significance of an idiom cannot be extracted from the 
individual meaning of words that make up the expression. Rather, the meaning is obtained as a whole.

McCarthy and O'Dell (2017) emphasized the importance of learning about idioms' meanings and how they are used. It is because English learners will come across a great many idioms when they listen and read English. It is said that a non-English speaker who can use idiomatic expressions is considered as close to English language proficiency (Rana, 2016). It is supported by many researchers (Fernando, 1996; Schmitt, 2000; Wray, 2000) that to have the ability to recognize idioms represents to reach the fluency of a native speaker.

Furthermore, Makkai (1972) breaks down idioms into two groups, namely idioms of encoding (identifiable) and idioms of decoding (non-identifiable). Encoding idioms are the quirky lexical mixes that have obvious meaning regarding collocational options and limitations, exemplified by what he drove at 70 m.p.h. While interpreting idioms, discuss those non-identifiable and deceptive lexical expressions, whose interpretations could not be comprehended over the factor discovered in linguistic conventions. Specifically, decoding idioms is unpredictable. Expressions such as you are pulling my leg is one example of this type of idiom. Decoding idiom is divided into two types of lexemic and sememic (Abdi \& Munandar, 2019). Nevertheless, this article merely discusses the first type, lexemic idioms.

The lexemic idioms are phrases which grouped in line with the natural grammatical feature (action words, things, adjective and relational word) and they are made out of more than one negligible free structure, and each lexicon can appear in different conditions as the acknowledgment of a monolexonic lexeme. It classifies into six different types, which are:

a. Phrasal verbs $\rightarrow$ to do over, come up with, look forward to

b. Tournures $\rightarrow$ jumping out of one's skin, kick the bucket

c. Irreversible compounds $\rightarrow$ separate but equal, coffee and cream

d. Phrasal compounds $\rightarrow$ breath fire, black ice

e. Incorporating verbs $\rightarrow$ quite down, man-handle

f. Pseudo-idioms $\rightarrow$ chit-chat, namby-pamby, spick and span

Furthermore, McCarthy and O'Dell classified idioms differently. It is based on their form. This classification resulted in seven types of idioms:

a) Verb + object or complement or adverbial $\rightarrow$ "carry two faces under one hood." 
b) Prepositional phrase $\rightarrow$ "unlike many others."

c) Compound $\rightarrow$ "A chicken in every pot."

d) Simile (as + adjective + as, or like + noun) $\rightarrow$ "a face like a mask," "as white as snow."

e) Binomial (word + and + word) $\rightarrow$ "odds and ends," "wear and tear."

f) Trinomial (word + word + and + word) $\rightarrow$ "gold, silver, and bronze," "small, medium and large."

g) Clause or sentence $\rightarrow$ "without further ado."

However, this investigation will use the classification as proposed by Makkai in grouping the idiomatic expressions produced by the participants. The data classified in this investigation is non - interactive speaking, i.e., the participants' self-speaking recording, which does not involve the immediate interlocutory when speaking.

\section{Speaking}

Figuring out how to communicate in another dialect is laden with a danger of disappointment or negative assessment. (Macintyre \& Gregersen, 2012). It is not unexpected, at that point, that language learners regularly battle to talk. The way that idiomatic expressions are so frequently experienced in both spoken and penned talk requires a utilization in and outside the study hall to help learners be serious, enhance their glossary and improve their English (Al-Khawaldeh et al., 2016). Other writers state that English talking is anything but a simple errand since speakers should realize numerous critical parts like utterance, sentence structure, glossary, familiarity, and understanding (Leong et al., 2017). As English is all around utilized as a correspondence method, particularly in the web world, English speaking abilities should be built alongside different aptitudes. These incorporated abilities will improve correspondence accomplishment both with local English speakers and different individuals from the worldwide network. There is plenty of meanings of "speaking" that have been recommended by experts in linguistics. (Boonkit, 2010). Generally, language learners have an issue in expressing themselves in oral language. For this reason, learners need to hone their speaking skills from all sides

\section{RESEARCH METHODOLOGY}


This research was carried out in IAIN Takengon among the students of the English Department. The participants were selected using purposive sampling. Namely, they have taken all Speaking courses (Speaking I - Speaking IV) and obtained the best score (all A or only one B of all). From the criteria, 21 students were opted to participate in this investigation. They are considered to possess better speaking skills and are supposed to use idiomatic expressions in their speaking.

Qualitative research is applied in this investigation. In the beginning, participants were suggested to record self-telling experiences for about 5 minutes. The record was collected and then analyzed by performing the following steps.

1. First, the record was transcribed into written text (transcript).

2. Second, idiomatic expressions were identified throughout the transcript. Subsequently, as much as detected idiom expressions were classified based on their types according to Makkai's theory about lexemic idioms. Six types of idiomatic expressions were classified here: phrasal verbs, tournures, irreversible, compounds, phrasal compounds, incorporating verbs, and pseudo-idioms.

3. The last step is to find out the most frequently used type of idioms. It was carried out by applying Arikunto's formula of percentage, i.e., $\mathrm{P}=\frac{F}{N} \times 100 \%$ in which $\mathrm{P}$ stands for percentage, $\mathrm{F}$ is the number of a certain type of idioms, $\mathrm{N}$ is the total number of all idioms (Arikunto, 2008). In detail, every idiom found in the transcript will be count individually.

4. From this analysis, the research questions are answered, and a description of the learners' idioms practice can be illustrated.

\section{FINDINGS AND DISCUSSION}

\section{Result}

From 20 transcripts of learners' around-5-minute-recordings, 23 idiomatic expressions were identified. A few of them were produced by more than one participant and counted as different parts (one idiom is counted as twice). For instance, get in is the idiom that comes from NS and SH. According to Idiom Free Dictionary by Farlex, get in means to enter some place or thing. Besides, the other idioms produced more than once were go through and last but not least: the former means to do something that one had planned or promised, despite difficulties, hesitations, or a concerning outcome, while the latter means 
emphasize that someone or something is still significant, despite being mentioned last in a list of people or things. From this, it can be concluded that the EFL learners in IAIN Takengon use idioms in their speaking, which answers the first research question: "Do EFL learners in IAIN Takengon use idiomatic expressions in their speaking?", and the answer is "yes, they do."

After identifying and calculating the number of idiomatic expressions, they are subsequently classified into idioms based on Makkai's theory about lexemic idioms. The result is presented in the following table:

Table 1. Idioms classification

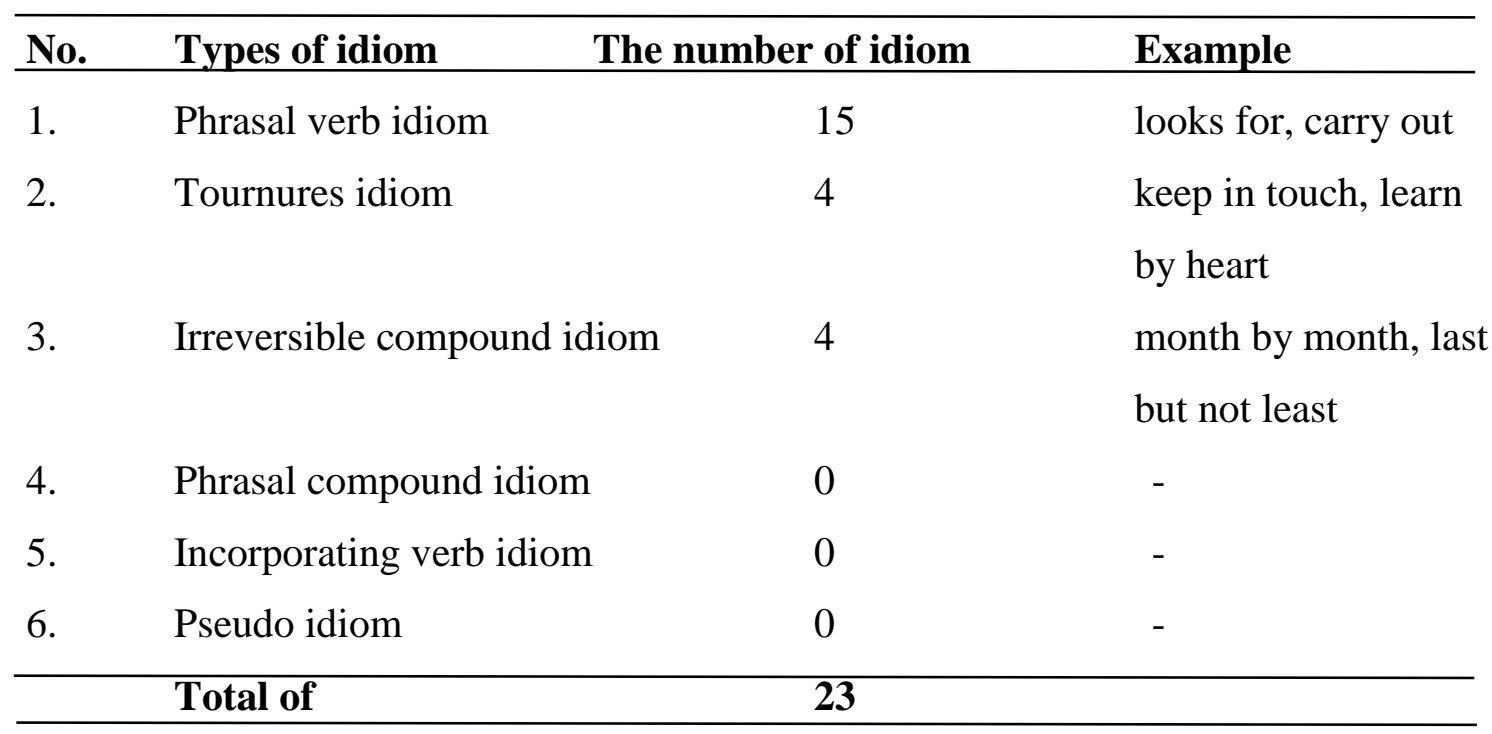

From table 1, it can likewise understand that the participants use the idiomatic expression, yet it appears to be that not all participants use them. It can be noticed that from the six types proposed, three of them were identified as phrasal verb idioms, tournures idioms, and irreversible compound idioms. While the other three were not found in the participant's self-telling record. Then, the finding provides the answer to the second question: what type of idioms do they produce in speaking? It can be summed up that the participants recognize and are familiar with the only three types of idioms. On the contrary, the participants do not recognize and are seemingly unfamiliar with phrasal compounds, incorporating verbs, and pseudo-idioms.

The subsequent step in data analysis is to provide the data in terms of percentage to look for the most dominant type of idiom practiced by the learners. It is displayed in the following table.

Table 2. Idioms percentage 


\begin{tabular}{llcc} 
No. & Types of idiom & The number of idiom & Percentage \\
\hline 1. & Phrasal verb idiom & 15 & $65.2 \%$ \\
2. & Tournures idiom & 4 & $17.4 \%$ \\
3. & Irreversible compound idiom & 4 & $17.4 \%$ \\
4. & Phrasal compound idiom & 0 & $0 \%$ \\
5. & Incorporating verb idiom & 0 & $0 \%$ \\
6. & Pseudo idiom & 0 & $0 \%$ \\
\hline & Total & $\mathbf{2 3}$ & $\mathbf{1 0 0} \%$ \\
\hline
\end{tabular}

Table 2 illustrates the frequency of each type of idioms that appeared in the participant's self-telling record. It can be seen that the first, phrasal verb idiom, is the most frequently used idioms by the participants, i.e., 15 expressions (65.2\%). Besides, tournures idiom and irreversible compound idiom are in the second rank, which is 4 expressions for each $(17.4 \%)$. Whereas the participants in their speaking do not apply the last three types of idioms. These findings provide an answer for the third research question: "What is the most frequently used idiom type in their speaking?". This answer can be further interpreted that phrasal verb idiom is the most familiar idiom among EFL learners. They recognize this type of idiom and use them easily is considered due to the sufficient exposure.

The data analysis for each participant needs to be grouped to establish a deeper portrait concerning the idiom used by them. The data is revealed in the table below.

Tabel 3. Idiom counting each participant

$\begin{array}{llr}\text { No } & \text { Participants (Initial Name) } & \text { The number } \\ \text { 1. } & \text { UM } & 0 \\ \text { 2. } & \text { HR } & 2 \\ \text { 3. } & \text { DH } & 0 \\ \text { 4. } & \text { LL } & 0 \\ \text { 5. } & \text { SD } & 0 \\ \text { 6. } & \text { SH } & 2 \\ \text { 7. } & \text { RW } & 3 \\ \text { 8. } & \text { PT } & 2 \\ \text { 9. } & \text { IR } & 2 \\ \text { 10. } & \text { AG } & 4 \\ \text { 11. } & \text { GS } & 1\end{array}$


13. IR 0

14. AM 0

15. $\mathrm{HH}$

16. $\mathrm{HF}$

17. LS 1

18. NS 1

19. SA 0

20. AR 0

Total of 23

Table 3 shows that only 12 of 20 participants use idiomatic expressions, while others use none of their speaking idioms. It indicates that idiom usage is not equally distributed among the participants. It is dominantly applied by a few of them, while other participants only use very few idioms, even almost half of the participants do not use any at all. From this result, it can be concluded that idiom usage among the EFL learners of the English Department in IAIN Takengon is considered poor. It is similar to (Al-Kadi's, 2015) finding that Yemeni EFL students are regarded to show low performance (lowesteem) at the idioms of English, hard to learn. (Tran, 2013) also, obtain a similar finding that the investigated students (EFL Learners in Vietnam) possess little knowledge of the common idioms, though most of them are aware of idioms' significance and learn them as a foreign language.

\section{Discussion}

Grabe and Stoller (Ho, 2018) claim that most native English students can read fluently with good comprehension, but they would have difficulty in doing grammar exercises on their reading. On the other hand, many EFL students have little fluency but considerable grammatical knowledge to do a test. In this case, EFL students do not need more grammatical knowledge but their fluency. Therefore, fluency in speaking needs to get more attention in the EFL teaching-learning process (Albino in (Ho, 2018). The spread of English, the promotion of English education, and the communicative purpose lead to many EFL learners in the world, especially in Indonesia. This reveals the importance of speaking fluently in the EFL class. As the outcome of this investigation revealed that the majority of participants did not apply idioms. Language learners need to be realized and conscious of enhancing their idiomatic understanding to assist their specific perspectives in the first-rate language and turn out to be extra successful. 
Moreover, EFL students need to enhance their relational abilities via idiom based learning.

A couple of instructing exercises and thoughts can be additionally intended for learning and utilizing idiomatic expressions inside and outside the study hall to broaden this investigation. Since for all intents and purposes, all idiomatic and conventionalized expressions are represented language and culture. The idiomatic didactic function can contribute to learners' key fluency advancement (Hinkel, 2017).

\section{CONCLUSIONS}

Several points regarding the utilization of idiomatic expression by EFL learners in IAIN Takengon can be concluded. First, as a participant, they used idioms in their speaking practice. Second, overall the types of idioms they used are phrasal verb idiom, tournures idiom, and irreversible idiom. There was no use of other idioms found in their data record. Third, a phrasal verb is the most frequently used by the participants of all these three types.

It can be wrapped up that idiomatic expressions are not prevalent widespread from the data distribution. Therefore, the use of idioms among the participant is reckoned poor. As stated previously, the more a non-indigenous speaker is equipped for comprehension and utilizing idiomatic expression, the closer the person is to the indigenous speaking capability and English fluency. The result signifies that the learners are still far from the native proficiency of English.

Regarding the result of this investigation, it is recommended that EFL learners of the English Department in IAIN Takengon are encouraged to exposure English more often to apply more idiomatic expressions in their speaking.

Further research is recommended as the continuity of this study to determine the intricacies that the learners probably encounter in recognizing, comprehending, and practicing idiomatic expressions.

\section{REFERENCES}

Abdi, H., \& Munandar, A. (2019). The Translation of Idioms in George Orwell's Animal Farm. Lexicon, 6(1), 38-50. https://journal.ugm.ac.id/lexicon/article/view/50307

Al-kadi, A. M. T. (2015). Towards Idiomatic Competence of Yemeni EFL Undergraduates. Journal of Language Teaching and Research, 6(3), 513-523. 
https://doi.org/10.17507/jltr.0603.06

Al-Khawaldeh, N., Jaradat, A., Al-Momani, H., \& Bani-Khair, B. (2016). Figurative idiomatic language: Strategies and difficulties of understanding English Idioms. International Journal of Applied Linguistics and English Literature, 5(6), 119-133. https://doi.org/10.7575/aiac.ijalel.v.5n.6p.119

Alata, M., Adiel, E., \& Ahmed, M. A. (2016). Difficulties Encountered by Sudanese Students in Translating Idiomatic Expressions from English into Arabic. International Journal of Humanities, Social Sciences, and Education, 3(6), 36-40. https://doi.org/10.20431/2349-0381.0306006

Arikunto, S. (2008). Dasar-Dasar Evaluasi Pendidikan. Jakarta: Bumi Aksara.

Asri, A. N. (2017). Innovative Teaching of English Idiomatic. Journal of English Teaching Adi Buana, 02(01), 47-58.

https://doi.org/10.36456/jet.v2.n01.2017.714

Bastug, H., \& Salihagic, S. (2014). Elaboration on Production of Idioms and Idiomatic Expressions by ESL Learners. Sakarya University Journal of Education, 4(2), 7284. https://doi.org/10.19126/suje.72442

Bobrow, S. A., \& Bell, S. M. (1973). On catching on to. 1(3), 343-346. https://link.springer.com/article/10.3758/BF03198118

Boonkit, K. (2010). Enhancing the development of speaking skills for non-native speakers of English. Procedia - Social and Behavioral Sciences, 2(2), 1305-1309. https://doi.org/10.1016/j.sbspro.2010.03.191

Cooper, T. C. (1999). Processing of Idioms by L2 Learners of English. TESOL Quarterly, 33(2), 233-262. https://doi.org/10.2307/3587719

Edith, E. R. D. C. (2009). The advantages and importance of learning and using idioms in english. Cuadernos de Lingüística Hispánica, 121-136. https://www.redalyc.org/pdf/3222/322227520009.pdf

Flor, M., \& Beigman Klebanov, B. (2018). Catching Idiomatic Expressions in EFL Essays. Proceedings of the Working on Figurative Language Processing, 34-44. https://www.aclweb.org/anthology/W18-0905.pdf

Hinkel, E. (2017). Teaching Idiomatic Expressions and Phrases: Insights and Techniques. Iranian Journal of Language Teaching Research, 5(3), 45-59. https://eric.ed.gov/?id=EJ1156200

Ho, P. V. P. (2018). Fluency as successful Communication. 1st National Conference on English Language Teaching Upgrade: A Focus on Fluency (CELTU 2018), 15-24. https://www.researchgate.net/profile/Pham_Ho2/publication/329584415_FLUENC Y_AS_SUCCESSFUL_COMMUNICATION/links/5c108fd892851c39ebe6b781/F LUENCY-AS-SUCCESSFUL-COMMUNICATION.pdf

Irujo, S. (1986). Don't Put Your Leg in Your Mouth: Transfer in the Acquisition of Idioms in a Second Language. TESOL Quarterly, 20(2), 287-304. https://doi.org/10.2307/3586545

Macintyre, P., \& Gregersen, T. (2012). Anxiety and Other Emotions in Language 
Learning. Psychology for Language Learning, 2012, 103-118. https://www.researchgate.net/publication/304799694_Affect_The_Role_of_Langua ge_Anxiety_and_Other_Emotions_in_Language_Learning

Maisa, S., \& Karunakaran, D. T. (2013). Idioms and importance of teaching idioms to ESL students: a study on teacher beliefs. Asian Journal of Humanities and Social Sciences (AJHSS), 1(1), 110-122.

http://ajhss.org/pdfs/Idioms and Importance of Teaching...pdf

McCarthy, M., \& Dell, F. O. (2017). English idioms in use - Intermediate. In Book (p. 182). Cambridge: Cambridge University Press.

Mei, L. L., \& Masoumeh, A. S. (2017). An Analysis of Factors Influencing Learners' English Speaking Skill. International Journal of Research in English Education, 2(1), 34-41.

https://www.sid.ir/en/journal/ViewPaper.aspx?ID=520992

Onjukka, R. (2011). A HOT-HEADED GRANDMA : The Use of Idiomatic Expressions in the Compositions of Finnish Upper Secondary School Students Bachelor 's Thesis (Issue April).

https://jyx.jyu.fi/bitstream/handle/123456789/37931/1/URN\%3ANBN\%3Afi\%3Aj yu-201205301767.pdf

Rana, A. T. (2016). The Necessity of idiomatic expressions to English Language learners. International Journal of English and Literature, 7(7), 106-111. https://doi.org/10.5897/ijel2016.0895

Tran, H. Q. (2013). Figurative Idiomatic Competence: An Analysis of EFL Learners in Vietnam. Language Education in Asia, 4(1), 23-38. https://doi.org/10.5746/leia/13/v4/i1/a3/tran

Vanderniet, K. H. (2015). Idioms as a Measure of Proficiency. A thesis submitted to the faculty of Brigham Young University in partial fulfillment of the requirements for the degree of Master of Arts. All Theses and Dissertations. 5817. https://scholarsarchive.byu.edu/etd/5817

Velasco, Y. P. (2016). Compositionality/non-compositionality of idioms: Non-native speakers' constraints to comprehension. Indonesian Journal of Applied Linguistics, 6(1), 135-144. https://doi.org/10.17509/ijal.v6i1.2745

Zarei, A. A., \& Rahimi, N. (2012). Idioms: Etymology, Contextual Pragmatic Clues, and Lexical Knowledge in Clues. Saarbrucken: LAMBERT Academic Publishing. 